\section{PSICOSE E PSICANÁLISE: O CASO ALTHUSSER}

A dor que emudece - travessia clínica de Louis Althusser, de Marci Dória Passos. Rio de Janeiro: Relume Dumará/Faperj, 2006, 179p.

\footnotetext{
Maria Tavares Cavalcanti

Professora adjunta do Departamento de Psiquiatria e Medicina Legal da Faculdade de Medicina da UFRJ; diretora clínica do Instituto de Psiquiatria da UFRJ.
}

A escolha de Marci Dória Passos em tomar Louis Althusser como um caso clínico, a fim de discutir as possibilidades, impasses, desafios e limites de uma (ou da) psicanálise, é, no mínimo, ousada. O filósofo francês, um dos pensadores mais reverenciados da segunda metade do século XX, é uma figura complexa, paradoxal, um “caraparte", como diria Passos.

A intenção ao tentar escrever sobre Althusser como um caso exemplar, nos diz a autora, é observar, e procurar situar em que medida a análise pessoal e o conhecimento teórico da psicanálise não previram, ou preveniram, várias experiências dramáticas e um desfecho trágico na vida do filósofo francês.

Esta ousadia, no entanto, nos presenteia com um excelente livro, no qual questões essenciais para a psicanálise contemporânea e também para a psiquiatria, são abordadas de forma corajosa $e$ bastante sensata.

É o próprio Althusser quem nos diz, em consonância com Freud e Lacan, que

"o destino humano adviria de um dizer" (p.21); aposta que possibilitou o advento da psicanálise e sua prática. Mas

"como face ao apelo angustiado de quem sofre, abster-se da vontade de calar a angústia e suportar que aquilo que produz dor encontre via da elaboração pela fala? (...) São momentos em que se impõe uma decisão, o que, se produz desconforto ao analista, não o desobriga do ato. Abrindo mão de corrigir, de prevenir, de salvar ou adaptar para o bem de determinada sociedade, a clínica psicanalítica só não deve escusar-se de tratar." (p.28-29)

A clínica psicanalítica só não deve escusar-se de tratar. Essa me parece ser a frase chave da aposta de Marci Dória Passos. Frente aos maiores desafios, e entre eles as psicoses, como manter a aposta na psicanálise? Como permanecer no lugar do analista? Que lugar seria esse no momento em que se colocam riscos efetivos à vida?

Pinel, considerado o "pai” da psiquiatria, já nos brindava com algumas indicações precisas: "quanto à ação com o paciente, Pinel condenava o ativismo terapêutico e o intervencionismo forçado e intempestivo. Para Pinel, conhecer bem o alienado era um meio de atingi-lo e tratá-lo" (p.32).

O analista de Althusser o conhecia bem e, mais do que isso, permaneceu ao seu lado quase por toda a vida, atravessando com ele numerosas internações - quando lhe fazia visitas diárias - períodos estes de grande fragmentação e angústia extrema. No entanto, nada disso evitou a tragédia do assassinato de Hélène por seu cliente.

"As construções de caso, a partir de pontuações determinadas pelo analista, recortam aquilo que seria o fantasma fundamental numa direção possível para o tratamento psicanalítico. São avanços significativos, imprescindíveis para a transmissão que orientam o trabalho analítico, mas não dão conta 
do real da clínica, bem mais complexo e difícil de atravessar. A tentativa de fechar com o saber a distância entre a prática e a teoria é impossível." (p.38)

No caso de Althusser, tanto ele como seu analista tinham domínio da teoria analítica e um saber bem construído sobre a constituição fantasmática do primeiro.

No entanto, como dissemos, o acontecimento terrível, envolvendo Hélène e Althusser - duas pessoas que, naquele momento, se tratavam com o mesmo psicanalista - ocorreu, e isto faz com que não possamos deixar de nos interrogar sobre os limites da psicanálise, do próprio psicanalista e sobre os efeitos do ato analítico no destino de um sujeito.

Impõe-se, assim, a questão sobre o lugar do analista na corrente do destino - destino representado pela trama desejante que envolve o Outro. O analista pode agir como contracorrente, possibilitando o esvaziamento do Outro e favorecendo o aparecimento do desejo do sujeito. Mas, se não há desejo fora do campo do Outro, que desejo seria esse? Qual seria o desejo do analista como operador em momentos radicais?

O que constitui um real irredutível aos esforços do sujeito e do analista, aquilo de que nenhuma análise dá conta? O que, na experiência precoce com os pais, tem "voz de oráculo" e se estabelece como um imperativo superegóico forçando a satisfação? Estaríamos sempre entre o destino como o inexorável de certas marcas ou também pela maneira como interpretamos o desejo materno, e os acasos, os fatos contingentes da vida.

Um ato inconsciente não exclui a responsabilidade pelas conseqüências daquilo que causa, e o sujeito desse ato tem responsabilidade sobre o mesmo (p.156-157)
"Mas como é possível que eu tenha matado Hélène?" era a pergunta que Althusser se fazia sem cessar e a todos que se aproximavam dele. Lutou muito também pelo direito de defesa, pois julgava muito pior do que a perda da liberdade a perda da responsabilidade por seu próprios atos.

Ao final, após muito sofrimento pode escrever em seu livro (O futuro dura muito tempo) essas palavras:

“(...) desde então creio ter aprendido o que quer dizer amar: ser capaz de não tomar essas iniciativas exageradas sobre si, mas de ser atento ao outro, respeitar seu desejo e seus ritmos, nada pedir, mas aprender a receber e receber cada presente como uma surpresa da vida, e ser capaz, sem nenhuma pretensão, do mesmo presente e da mesma surpresa para o outro, sem lhe fazer a menor violência. Em suma, a simples liberdade. Por que, afinal, Cézanne pintou a montanha Sainte-Victoire a cada instante? É porque a luz de cada instante é um presente.

Então, a vida ainda pode, apesar de seus dramas ser bela. Tenho 67 anos, mas finalmente sinto-me, eu que não tive juventude, pois não fui amado por mim mesmo, sinto-me jovem como nunca, ainda que a história deva acabar brevemente.

Sim, o futuro dura muito tempo." (ALTHUSSER, 1992, p.244 e 245, apud, PASSOS, 2006, p.1690

Todas essas observações foram feitas com o intuito de que o leitor sinta-se convidado a mergulhar nas reflexões da autora, recuperando assim o vigor da psicanálise e a riqueza que ela nos oferece em termos de reflexão teórica e ação prática, mesmo em casos extremamente difíceis e desafiadores. Há um lugar privilegiado 
para a psicanálise na clínica das psicoses e a travessia clínica de Louis Althusser, em seu aparente "fracasso", revela-se a partir da leitura do livro de Passos numa fascinante viagem, que permite ao filósofo aos 67 anos escrever: "Então, a vida ainda pode, apesar de seus dramas, ser bela."

Recebida em 22/12/2006

Aprovada em 18/1/2007.

Maria Tavares Cavalcanti

(mtavares@ipub.ufrj.br) 